\title{
Fishing Industry Waste Water Treatment by Polyelectrolytes
}

\author{
Navami. D ${ }^{1}$, M.A Chinnamma ${ }^{2}$ \\ ${ }^{1}$ Department of Environmental Engineering, Kerala Technical University, Thiruvanathapuram, India \\ ${ }^{2}$ Professor, Environmental Engineering, MCET Trissur, Kerala, India
}

\begin{abstract}
The fishing industries consume huge amount of water and also produce tonnes of waste water from fish preservation and fish tanks. The fishing industry wastewater treatment can be done by sequence of treatment processes such as sedimentation, coagulation. Characteristics of fishing industry wastewater are the color is light brown, $\mathrm{pH}$ is 8, COD is $576.0 \mathrm{mg} / \mathrm{l,} \mathrm{BOD}_{3}$ is $185.0 \mathrm{mg} / \mathrm{l}$, VSS is $0.56 \mathrm{mg} / \mathrm{L}$, TSS is $110.5 \mathrm{mg} / \mathrm{l}$, conductivity is $39300.0 \mu \mathrm{s} / \mathrm{cm}$, oil and grease is $2.1 \mathrm{mg} /$, fecal coliform is >2400MPN, total phosphorous is $22.6 \mathrm{mg} /$, total nitrogen is $60.0 \mathrm{mg} / \mathrm{l}$, ammonical nitrogen is $<0.05$, TOC is $20.8 \mathrm{mg} / \mathrm{l}$ and turbidity is 3.9NTU. The optimum dosage of aluminium chloride as a polyelectrolyte is found to be $100 \mathrm{mg} /$, optimum $\mathrm{pH}$ is 7 and optimum time $30 \mathrm{~min}$. The reduction in turbidity for the fishing industry wastewater is $79 \%$, reduction in $\mathrm{BOD}_{3}$ is $65 \%$, reduction in COD is 66\%, reduction in TSS is $87 \%$ and reduction in VSS is $61 \%$, conductivity is $41 \%$, oil and grease is $90 \%$, total phosphorous is $94 \%$, total nitrogen is $67 \%$ and TOC is $95 \%$ by the influence of the polyelectrolyte aluminium chloride. Optimum dosage of bentonite clay is $500 \mathrm{mg} /$, optimum $\mathrm{pH}$ is 6 and optimum time 45min. The reduction in turbidity for the fishing industry waste water is $62 \%$, reduction in $\mathrm{BOD}_{3}$ is $58 \%$, reduction in COD is $61 \%$, reduction in TSS is $80 \%$ and reduction in VSS is $73 \%$, conductivity is $40 \%$, oil and grease is $81 \%$, total phosphorous is $92 \%$, total nitrogen is $50 \%$ and TOC is $94 \%$ by the influence of the polyelectrolyte bentonite clay. Optimum dosage of ferrous sulphate monohydrate is $300 \mathrm{mg} / \mathrm{l}$, optimum $\mathrm{pH}$ is 7 and optimum time 45min. The reduction in turbidity for the fishing industry wastewater is $18 \%$, reduction in $\mathrm{BOD}_{3}$ is $49 \%$, reduction in COD is $56 \%$, reduction in TSS is $69 \%$ and reduction in VSS is 39\%, conductivity is 30\%, oil and grease is $76 \%$, total phosphorous is $93 \%$ and TOC is $94 \%$ by the influence of the polyelectrolyte ferrous sulphate monohydrate. There is no change in fecal coliform and ammonical nitrogen by the effect of these polyelectrolytes. Similarly there is no change in total nitrogen by the effect of ferrous sulphate monohydrate.
\end{abstract}

Keywords- BOD-Biochemical oxygen demand, CODChemical oxygen demand, TOC-Total organic carbon,
TSS-Total suspended solids, VSS-Volatile suspended solids

\section{INTRODUCTION}

Water pollution and water scarcity is a crucial environmental problem in India. The total amount of waste water generated from all Industries is about 83,048 mid. Total amount of waste water generated from fishing industries is about $14,300 \mathrm{~m}^{3}$ daily. Fishing industry generates waste water with high content of compounds such as nitrogen, phosphorous, organic matter, salts, oil and grease. The effluents from these industries are subjected to a sequence of treatment processes to reduce the concentration of effluents. Effluents treatment are done to attain quality water for reuse and recycling of theses water for industrial processes. Water recycling means reusing treated wastewater for purposes such as agricultural and irrigation, industrial processes, domestic use etc. The previous work focuses on the treatment of fishing industry waste water by other polyelectrolytes and $100 \%$ removal efficiency is not attained. This work aims to make fishing industry more co efficient by reuse or recycling of waste water after treatment of waste water using polyelectrolytes such as Bentonite clay, Aluminium chloride and Ferrous sulphate mono hydrate. This work also evaluate the removal efficiencies of these three electrolytes and also analyze the parameters such as color, TSS, volatile suspended solids, TOC, COD, BOD, total phosphorous, total nitrogen, ammonical nitrogen, fecal coliform removal, conductivity, fats, oil and grease and $\mathrm{pH}$.

\section{MATERIALS AND METHODS}

\subsection{Materials}

The polyelectrolytes such as Bentonite clay, Aluminium chloride and Ferrous sulphate mono hydrate is used for treatment of fishing industry wastewater. The polyelectrolytes are collected from Chemind chemicals at Trissur. The fishing industry waste water is collected from Azhikode Jetty (Govt. of Kerala, Department of Fisheries and Regional Shrimp Hatchery) Azhikode in Trissur district 


\subsection{Methods}

\subsubsection{Sedimentation}

Sedimentation test using graduated cylinder is done before coagulation. The waste water taken in graduated cylinder is left undisturbed for a period of 2 hours. A sampling port is attached with graduated cylinder, $10 \mathrm{~cm}$ from the bottom, such that water from the middle layer is taken. The fishing industry waste water characteristics are evaluated after sedimentation.

\section{EXPERIMENTAL SET UP}

Coagulation-flocculation can be employed by standard jar test. Three different polyelectrolytes such as Bentonite clay, Aluminium chloride and Ferrous sulphate mono hydrate is used. Several dosages of polyelectrolytes are taken. The dosages taken are $100 \mathrm{mg} / \mathrm{L}, 200 \mathrm{mg} / \mathrm{L}$, $300 \mathrm{mg} / \mathrm{L}, 400 \mathrm{mg} / \mathrm{L}, 500 \mathrm{mg} / \mathrm{L}$ and $600 \mathrm{mg} / \mathrm{L}$. Middle layer water from the graduated cylinder after sedimentation is taken and filled in each jar of $1000 \mathrm{~mL}$ and various coagulant dosages are added in each jar. Paddles are rotated at $150 \mathrm{rpm}$ for $3 \mathrm{~min}$ for rapid mixing for floc formation. Paddles are rotated at $20 \mathrm{rpm}$ for $15 \mathrm{~min}$. Finally, it is left undisturbed for the flocs to settle. The supernatants is taken for analysis.

\section{RESULTS AND DISCUSSIONS}

\subsection{Initial characteristics of waste water}

The initial characteristics of fishing industry waste water such as color, $\mathrm{pH}$, turbidity, BOD, COD, volatile suspended solids, total suspended solids, conductivity, oil and grease, fecal coliform, total phosphorous, total nitrogen, ammonical nitrogen, total organic carbon are being observed.

Table.1: Initial characteristics of waste water

\begin{tabular}{|c|c|c|}
\hline Parameters & Unit & Value \\
\hline Color & - & Light brown \\
\hline $\mathrm{pH}$ & - & 8.0 \\
\hline Turbidity & $\mathrm{NTU}$ & 3.9 \\
\hline $\mathrm{COD}$ & $\mathrm{Mg} / \mathrm{L}$ & 576.0 \\
\hline BOD & $\mathrm{Mg} / \mathrm{L}$ & 185.0 \\
\hline $\mathrm{TSS}$ & $\mathrm{Mg} / \mathrm{L}$ & 110.5 \\
\hline VSS & $\mathrm{Mg} / \mathrm{L}$ & 0.56 \\
\hline Conductivity & $\mu \mathrm{s} / \mathrm{cm}$ & 39300.0 \\
\hline Oil and grease & $\mathrm{Mg} / \mathrm{L}$ & 2.1 \\
\hline Coliform & $\mathrm{MPN}$ & $>2400$ \\
\hline Total phosphorous & $\mathrm{Mg} / \mathrm{L}$ & 22.6 \\
\hline Total nitrogen & $\mathrm{Mg} / \mathrm{L}$ & 60 \\
\hline Ammonical nitrogen & $\mathrm{Mg} / \mathrm{L}$ & $<0.05$ \\
\hline Total organic carbon & $\mathrm{Mg} / \mathrm{L}$ & 20.8 \\
\hline
\end{tabular}

\subsection{Characteristics of waste water after sedimentation}

The characteristics of fishing industry waste water after sedimentation are being analyzed. such as color, $\mathrm{pH}$, turbidity, BOD, COD, volatile suspended solids, total suspended solids, conductivity, oil and grease, fecal coliform, total phosphorous, total nitrogen, ammonical nitrogen, total organic carbon are being observed.

Table. 2: Characteristics of waste water after sedimentation

\begin{tabular}{|c|c|c|}
\hline Parameters & Unit & Value \\
\hline Color & - & Light brown \\
\hline $\mathrm{pH}$ & - & 8.0 \\
\hline Turbidity & $\mathrm{NTU}$ & 3.9 \\
\hline $\mathrm{COD}$ & $\mathrm{Mg} / \mathrm{L}$ & 576.0 \\
\hline BOD & $\mathrm{Mg} / \mathrm{L}$ & 185.0 \\
\hline $\mathrm{TSS}$ & $\mathrm{Mg} / \mathrm{L}$ & 53 \\
\hline VSS & $\mathrm{Mg} / \mathrm{L}$ & 0.42 \\
\hline Conductivity & $\mu \mathrm{s} / \mathrm{cm}$ & 39300.0 \\
\hline Oil and grease & $\mathrm{Mg} / \mathrm{L}$ & 1.3 \\
\hline Coliform & $\mathrm{MPN}$ & $>2400$ \\
\hline Total phosphorous & $\mathrm{Mg} / \mathrm{L}$ & 22.6 \\
\hline Total nitrogen & $\mathrm{Mg} / \mathrm{L}$ & 60 \\
\hline Ammonical nitrogen & $\mathrm{Mg} / \mathrm{L}$ & $<0.05$ \\
\hline Total organic carbon & $\mathrm{Mg} / \mathrm{L}$ & 20.8 \\
\hline
\end{tabular}

\subsection{Optimum dosage}

The optimum dosage of polyelectrolytes are determined by varying the dosage of polyelectrolytes as $100 \mathrm{mg} / \mathrm{l}$, $200 \mathrm{mg} / \mathrm{l}, 300 \mathrm{mg} / \mathrm{l}, 400 \mathrm{mg} / \mathrm{l}, 500 \mathrm{mg} / \mathrm{l}$ and $600 \mathrm{mg} / \mathrm{l}$ at original $\mathrm{pH}$ of fishing industry wastewater $(\mathrm{pH}=8.0)$. The optimum dosage adopted for polyelectrolytes are $100 \mathrm{mg} / \mathrm{l}$ for aluminium chloride, $500 \mathrm{mg} / \mathrm{l}$ for bentonite clay and $300 \mathrm{mg} / \mathrm{l}$ for ferrous sulphate monohydrate.

\subsection{Optimum pH}

The optimum $\mathrm{pH}$ of polyelectrolytes are determined by varying the $\mathrm{pH}$ of polyelectrolytes as $3,4,5,6,7$ and 8 . The optimum $\mathrm{pH}$ adopted for polyelectrolytes are 7 for aluminium chloride, 6 for bentonite clay and 7 for ferrous sulphate monohydrate.

\subsection{Optimum time}

The optimum time of polyelectrolytes are determined by varying the time intervals of polyelectrolytes as $15 \mathrm{~min}$, $30 \mathrm{~min}$, 45min, 60min, $75 \mathrm{~min}$ and $90 \mathrm{~min}$. The optimum time adopted for polyelectrolytes are $30 \mathrm{~min}$ for aluminium chloride, $45 \mathrm{~min}$ for bentonite clay and $45 \mathrm{~min}$ for ferrous sulphate monohydrate.

\subsection{Final characteristics of waste water}

Fishing industry waste water is being treated with polyelectrolytes aluminium chloride, bentonite clay, 
ferrous sulphate monohydrate with optimum dosage, optimum $\mathrm{pH}$ and optimum time and final characteristics of treated fishing industry waste water is being analyzed.

\subsection{Effect of aluminium chloride}

Fishing industry waste water is being treated with polyelectrolyte aluminium chloride with optimum dosage of $100 \mathrm{mg} / \mathrm{l}$, optimum $\mathrm{pH} 7$ and optimum time of $30 \mathrm{~min}$ and final characteristics of treated fishing industry waste water is being analyzed.

Table.3: Final characteristics of waste water treated by aluminium chloride

\begin{tabular}{|c|c|c|}
\hline Parameters & Unit & $\begin{array}{c}\text { Aluminium } \\
\text { chloride }\end{array}$ \\
\hline Color & - & Colorless \\
\hline $\mathrm{pH}$ & - & 7.0 \\
\hline Turbidity & $\mathrm{NTU}$ & 0.8 \\
\hline $\mathrm{COD}$ & $\mathrm{Mg} / \mathrm{L}$ & 196.0 \\
\hline $\mathrm{BOD}$ & $\mathrm{Mg} / \mathrm{L}$ & 65.0 \\
\hline $\mathrm{TSS}$ & $\mathrm{Mg} / \mathrm{L}$ & 14.5 \\
\hline $\mathrm{VSS}$ & $\mathrm{Mg} / \mathrm{L}$ & 0.22 \\
\hline Conductivity & $\mu \mathrm{s} / \mathrm{cm}$ & 23240.0 \\
\hline Oil and grease & $\mathrm{Mg} / \mathrm{L}$ & 0.2 \\
\hline Coliform & $\mathrm{MPN}$ & $>2400$ \\
\hline Total phosphorous & $\mathrm{Mg} / \mathrm{L}$ & 1.38 \\
\hline Total nitrogen & $\mathrm{Mg} / \mathrm{L}$ & 20 \\
\hline Ammonical nitrogen & $\mathrm{Mg} / \mathrm{L}$ & $<0.05$ \\
\hline Total organic carbon & $\mathrm{Mg} / \mathrm{L}$ & 1.10 \\
\hline
\end{tabular}

\subsection{Efficiency of aluminium chloride}

To determine the efficiency of aluminium chloride, the optimum dosage, optimum $\mathrm{pH}$ and optimum time can be maintained. Optimum dosage is $100 \mathrm{mg} / \mathrm{l}$, optimum $\mathrm{pH}$ is 7 and optimum time 30min. The reduction in turbidity is $79 \%$, reduction in $\mathrm{BOD}_{3}$ is $65 \%$, reduction in $\mathrm{COD}$ is $66 \%$, reduction in total suspended solids is $87 \%$ and reduction in volatile suspended solids is $61 \%$, conductivity is $41 \%$, oil and grease is $90 \%$, total phosphorous is $94 \%$, total nitrogen is $67 \%$ and total organic carbon is $95 \%$.

\subsection{Effect of bentonite clay}

Fishing industry waste water is being treated with polyelectrolyte bentonite clay with optimum dosage of $500 \mathrm{mg} / \mathrm{l}$, optimum $\mathrm{pH} 6$ and optimum time of $45 \mathrm{~min}$ and final characteristics of treated fishing industry waste water is being analyzed.

Table.4: Final characteristics of waste water treated by bentonite clay

\begin{tabular}{|c|c|c|}
\hline Parameters & Unit & Bentonite clay \\
\hline Color & - & Colorless \\
\hline $\mathrm{pH}$ & - & 6.0 \\
\hline Turbidity & NTU & 1.5 \\
\hline
\end{tabular}

\begin{tabular}{|c|c|c|}
\hline COD & $\mathrm{Mg} / \mathrm{L}$ & 224.0 \\
\hline BOD & $\mathrm{Mg} / \mathrm{L}$ & 78.0 \\
\hline TSS & $\mathrm{Mg} / \mathrm{L}$ & 22.1 \\
\hline VSS & $\mathrm{Mg} / \mathrm{L}$ & 0.15 \\
\hline Conductivity & $\mu \mathrm{s} / \mathrm{cm}$ & 23550.0 \\
\hline Oil and grease & $\mathrm{Mg} / \mathrm{L}$ & 0.4 \\
\hline Coliform & $\mathrm{MPN}$ & $>2400$ \\
\hline Total phosphorous & $\mathrm{Mg} / \mathrm{L}$ & 1.86 \\
\hline Total nitrogen & $\mathrm{Mg} / \mathrm{L}$ & 30 \\
\hline Ammonical nitrogen & $\mathrm{Mg} / \mathrm{L}$ & $<0.05$ \\
\hline Total organic carbon & $\mathrm{Mg} / \mathrm{L}$ & 1.25 \\
\hline
\end{tabular}

\subsection{Efficiency of bentonite clay}

To determine the efficiency of bentonite clay, the optimum dosage, optimum $\mathrm{pH}$ and optimum time can be maintained. Optimum dosage is $500 \mathrm{mg} / \mathrm{l}$, optimum $\mathrm{pH}$ is 6 and optimum time $45 \mathrm{~min}$. The reduction in turbidity is $62 \%$, reduction in $\mathrm{BOD}_{3}$ is $58 \%$, reduction in COD is $61 \%$, reduction in total suspended solids is $80 \%$ and reduction in volatile suspended solids is $73 \%$, conductivity is $40 \%$, oil and grease is $81 \%$, total phosphorous is $92 \%$, total nitrogen is $50 \%$ and Total organic carbon is $94 \%$.

\subsection{Effect of ferrous sulphate monohydrate}

Fishing industry waste water is being treated with polyelectrolyte ferrous sulphate monohydrate with optimum dosage of $300 \mathrm{mg} / \mathrm{l}$, optimum $\mathrm{pH} 7$ and optimum time of $45 \mathrm{~min}$ and final characteristics of treated fishing industry waste water is being analyzed.

Table. 4: Final characteristics of waste water treated by ferrous sulphate monohydrate

\begin{tabular}{|c|c|c|}
\hline Parameters & Unit & $\begin{array}{c}\text { Ferrous sulphate } \\
\text { monohydrate }\end{array}$ \\
\hline Color & - & Light brown \\
\hline $\mathrm{pH}$ & - & 7.0 \\
\hline Turbidity & $\mathrm{NTU}$ & 3.2 \\
\hline $\mathrm{COD}$ & $\mathrm{Mg} / \mathrm{L}$ & 256.0 \\
\hline $\mathrm{BOD}$ & $\mathrm{Mg} / \mathrm{L}$ & 94.0 \\
\hline $\mathrm{TSS}$ & $\mathrm{Mg} / \mathrm{L}$ & 34.5 \\
\hline $\mathrm{VSS}$ & $\mathrm{Mg} / \mathrm{L}$ & 0.34 \\
\hline Conductivity & $\mu \mathrm{s} / \mathrm{cm}$ & 27345.0 \\
\hline Oil and grease & $\mathrm{Mg} / \mathrm{L}$ & 0.5 \\
\hline Coliform & $\mathrm{MPN}$ & $>2400$ \\
\hline $\begin{array}{c}\text { Total } \\
\text { phosphorous }\end{array}$ & $\mathrm{Mg} / \mathrm{L}$ & 1.52 \\
\hline $\begin{array}{c}\text { Total nitrogen } \\
\text { Ammonical } \\
\text { nitrogen }\end{array}$ & $\mathrm{Mg} / \mathrm{L}$ & 60 \\
\hline $\begin{array}{c}\text { Total organic } \\
\text { carbon }\end{array}$ & $\mathrm{Mg} / \mathrm{L}$ & $<0.05$ \\
\hline
\end{tabular}




\subsection{Efficiency of ferrous sulphate monohydrate}

To determine the efficiency of ferrous sulphate monohydrate, the optimum dosage, optimum $\mathrm{pH}$ and optimum time can be maintained. Optimum dosage is $300 \mathrm{mg} / 1$, optimum $\mathrm{pH}$ is 7 and optimum time $45 \mathrm{~min}$. The reduction in turbidity for the fishing industry wastewater is $18 \%$, reduction in $\mathrm{BOD}_{3}$ is $49 \%$, reduction in $\mathrm{COD}$ is $56 \%$, reduction in total suspended solids is $69 \%$ and reduction in volatile suspended solids is $39 \%$, conductivity is $30 \%$, oil and grease is $76 \%$, total phosphorous is $93 \%$ and total organic carbon is $94 \%$ by the influence of the polyelectrolyte ferrous sulphate monohydrate.

\section{CONCLUSION}

The characteristics of fishing industry wastewater are color is light brown, $\mathrm{pH}$ is $8, \mathrm{COD}$ is $576.0 \mathrm{mg} / \mathrm{l}, \mathrm{BOD}_{3}$ is $185.0 \mathrm{mg} / \mathrm{l}$, volatile suspended solids is $0.56 \mathrm{mg} / \mathrm{L}$, total suspended solids is $110.5 \mathrm{mg} / \mathrm{l}$, conductivity is $39300.0 \mu \mathrm{s} / \mathrm{cm}$, oil and grease is $2.1 \mathrm{mg} / \mathrm{l}$, fecal coliform is $>2400 \mathrm{MPN}$, total phosphorous is $22.6 \mathrm{mg} / \mathrm{l}$, total nitrogen is $60.0 \mathrm{mg} / \mathrm{l}$, ammonical nitrogen is $<0.05$, total organic carbon is $20.8 \mathrm{mg} / \mathrm{l}$ and turbidity is $3.9 \mathrm{NTU}$. The optimum dosage of aluminium chloride as a polyelectrolyte is found to be $100 \mathrm{mg} / \mathrm{l}$, optimum $\mathrm{pH}$ is 7 and optimum time $30 \mathrm{~min}$. The reduction in turbidity for the fishing industry wastewater is $79 \%$, reduction in $\mathrm{BOD}_{3}$ is $65 \%$, reduction in COD is $66 \%$, reduction in total suspended solids is $87 \%$ and reduction in volatile suspended solids is $61 \%$, conductivity is $41 \%$, oil and grease is $90 \%$, total phosphorous is $94 \%$, total nitrogen is $67 \%$ and total organic carbon is $95 \%$ by the influence of the polyelectrolyte aluminium chloride. Optimum dosage of bentonite clay is $500 \mathrm{mg} / \mathrm{l}$, optimum $\mathrm{pH}$ is 6 and optimum time $45 \mathrm{~min}$. The reduction in turbidity for the fishing industry wastewater is $62 \%$, reduction in $\mathrm{BOD}_{3}$ is $58 \%$, reduction in COD is $61 \%$, reduction in total suspended solids is $80 \%$ and reduction in volatile suspended solids is $73 \%$, conductivity is $40 \%$, oil and grease is $81 \%$, total phosphorous is $92 \%$, total nitrogen is $50 \%$ and total organic carbon is $94 \%$ by the influence of the polyelectrolyte bentonite clay. Optimum dosage of ferrous sulphate monohydrate is $300 \mathrm{mg} / \mathrm{l}$, optimum $\mathrm{pH}$ is 7 and optimum time $45 \mathrm{~min}$. The reduction in turbidity for the fishing industry wastewater is $18 \%$, reduction in $\mathrm{BOD}_{3}$ is $49 \%$, reduction in COD is $56 \%$, reduction in total suspended solids is $69 \%$ and reduction in volatile suspended solids is $39 \%$, conductivity is $30 \%$, oil and grease is $76 \%$, total phosphorous is $93 \%$ and total organic carbon is $94 \%$ by the influence of the polyelectrolyte ferrous sulphate monohydrate. Hence aluminium chloride as a polyelectrolyte is effective for treatment of fishing industry wastewater, and the treated fishing industry waste water can be used for irrigational purposes. This study focuses on the fishing industry waste water treatment by using polyelectrolytes such as aluminium chloride, bentonite clay and ferrous sulphate monohydrate by varying dosage, $\mathrm{pH}$ ant time. The scope of further study can be done by varying temperature, salt, sequence of chemical addition and rapid mixing.

\section{ACKNOWLEDGEMENTS}

An acknowledgement section may be presented after the conclusion, if desired.

\section{REFERENCES}

[1] G. M. Silva "Application of coagulants in pretreatment of fish wastewater using factorial design”, http://dx.doi.org/10.5004/dwt.2009.123, Pages 208-214, Received 20 Nov 2007, Accepted 04 Aug 2008, Published online: 03 Aug 2012

[2] Aikaterini Kassaveti "Fish industry waste: treatments, environmental impacts, current and potential uses", 8 October 2007

[3] Juan B. Justo "Solids removal by coagulation from fisheries waste waters", ISSN 0378-4738, Water SA Vol. 24 No. 4 October 1998

[4] Martins Olusola Ogedengbe "Polyelectrolites in the treatment of waste water", Retrospective Theses and Dissertations, Paper, 4765, 1972

[5] Mikel E. Goldblatt "New Polyelectrolyte Emulsion Breaker Improves Oily Wastewater Cleanup at Lower Usage Rates", 2014

[6] Rac "Pollution Prevention in Food Canning Processes", Regional Activity Centre for Cleaner Production (RAC/CP), Mediterranean Action Plan, March 2001

[7] Rafael Lazzari "Nitrogen and phosphorus waste in fish farming", 34(4):591-600 · January 2008 